\title{
PERBANDINGAN PERMAINAN EDUKATIF DAN ANIMASI VIRTUAL TERHADAP HASIL BELAJAR MATEMATIKA DITINJAU DARI KEAKTIFAN SISWA
}

\author{
Eka Kurnia*1 \\ ${ }^{1}$ Universitas Muhammadiyah Prof. Dr. HAMKA \\ i840@ymail.com ${ }^{1}$
}

\begin{abstract}
This research aims to compare educational games and virtual animations to mathematics learning outcomes in terms of student activity. The research was conducted on fourth grade of SDN Jatirangga I Bekasi. The sampling technique used cluster sampling technique. Method used is a quasi experimental design method. Furthermore, the normality and homogeneity prerequisite tests were carried out to show the normal and homogeneous data groups. After that, hypothesis testing using two-way ANNAVA obtained interaction $t_{\text {count }}(I)=4.03$ at the significance level of $0.05 t_{\text {table }}=3.96$ because tcount $>t_{\text {table }}$ then Ho was rejected. Thus, it means is an interaction between learning media and student activity towards mathematics learning outcomes. Because there is an interaction, Tukey's further test is carried out which gets the first result, namely $Q_{\text {count }}=4.85$ while at $\alpha 0.05 \mathrm{dbv1}=4$ and $\mathrm{dbv} 2=20$ indicates $Q$ table $=3.96$. because $Q_{\text {count }}>Q_{\text {table }}$ then $H o$ is rejected, it can be concluded that there are differences in mathematics learning outcomes using educational games and virtual animation on the low category of student activity. The second Tukey test shows the results, namely $Q_{\text {count }}=0.84$ and $Q_{\text {table }}=3.96$. It is concluded that $0.84<3.96$ or $Q_{\text {count }}<Q_{\text {table }}$ then Ho is accepted, it can be concluded that there is no difference in learning outcomes of mathematics using educational games and virtual animation on high category student activity.
\end{abstract}

Keywords: Games, Educational, Animation, Virtual, Mathematics.

\begin{abstract}
Abstrak
Penelitian ini bertujuan membandingkan hasil belajar matematika antara yang menggunakan Permainan Edukatif dan Animasi Virtual ditinjau dari Keaktifan Siswa. Penelitian dilakukan terhadap siswa kelas IV SDN Jatirangga I Kota Bekasi. Teknik pengambilan sampel yang digunakan adalah teknik cluster sampling dan metode penelitian yang digunakan adalah metode quasi eksperimental design. Selanjutnya peneliti melakukan uji prasyarat normalitas dan homogenitas untuk menunjukan kelompok data berdistribusi normal dan homogen. Setelah itu uji hipotesis menggunakan ANNAVA dua jalur diperoleh $t_{\text {hitung }}$ interaksi $(I)=4,03$ pada taraf signifikansi $0,05 t_{\text {tabel }}=\mathbf{3 , 9 6}$ sehingga $t_{\text {hitung }}>t_{\text {tabel. }}$. Artinya maka Ho ditolak dan terdapat interaksi antara media pembelajaran dan keaktifan siswa terhadap hasil belajar matematika. Jika terdapat interaksi maka perlu dilakukan uji lanjut Tukey. Adapun hasil pertama, yaitu $Q_{\text {hitung }}=4,85$ sedangkan pada $\alpha 0,05 \mathrm{db}_{\mathrm{v} 1}=4 \mathrm{dan} \mathrm{db}_{\mathrm{v} 2}=20$ menunjukan $\mathrm{Q}_{\text {tabel }}=3,96$. karena $Q_{\text {hitung }}>\mathrm{Q}_{\text {tabel }}$ maka Ho ditolak dan disimpulkan terdapat perbedaan hasil belajar matematika yang menggunakan permainan edukatif dan animasi virtual pada keaktifan siswa kategori rendah. Uji Tukey kedua menunjukan hasil yaitu $\mathrm{Q}_{\text {hitung }}=0,84$ dan $\mathrm{Q}_{\text {tabel }}=3,96$. diperoleh kesimpulan $\mathbf{0 , 8 4}<\mathbf{3 , 9 6}$ atau $\mathrm{Q}_{\text {hitung }}<$ $\mathrm{Qt}_{\text {abel }}$ maka $\mathrm{H}_{\mathrm{o}}$ diterima dapat disimpulkan tidak terdapat perbedaan hasil belajar matematika menggunakan permainan edukatif dan animasi virtual pada keaktifan siswa kategori tinggi.
\end{abstract}

Kata kunci : Permainan, Edukatif, Animasi, Virtual, Matematika. 


\section{PENDAHULUAN}

Dalam surat An Nahl ayat ke-78 yang berbunyi:

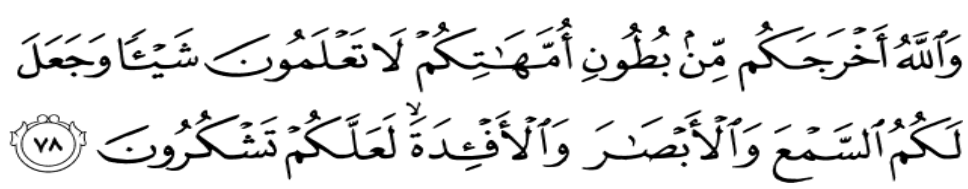

Artinya: “ Dan Allah telah mengeluarkan kamu dari perut ibu kamu, dalam keadaan tidak mengetahui sesuatu apapun, dan Dia memberimu pendengaran, penglihatan dan hati nurani, agar kamu bersyukur.” (An Nahl:78)

Menurut tafsir Al-Azhar yang ditulis oleh Prof.DR.Hamka saat dilahirkan tidak ada yang kita ketahui, selain anugerah ilahi yang dinamakan gharizah atau naluri. Menangis saat merasa dingin, meangis saat merasa lapar. Kemudian berangsur-angsur tumbuhlah pendengara, lalu ditumbuhkan pula penglihatan. Pendengaran, penglihatan dan perkembangan hati yaitu perasaan dan pikiran. Sampai berangsur besar, bertambah dewasa, sampai menjadi manusia yang berbudi bahasa, sopan dan santun, sanggup memikul tanggung jawab menjadi anggota penuh perikemanusiaan. Kemudian bersyukur dengan mempergunakan nikmat-nikmat Allah itu.

Pada tafsir diatas jelas dikatakan bahwa kita tidak memiliki pengetahuan kemudian dianugerahi pendengaran dan penglihatan untuk mencari tahu serta dapat bijaksana mensyukuri nikmat yang diberikan Allah tersebut. Dengan demikian penggunaan media pada pembelajaran sebagai sebuah penunjang dalam proses pembelajaran perlu disesuaikan agar dapat diterima oleh pendengaran dan penglihatan kita sehingga menghasilkan pembelajaran yang efektif. Hal tersebut sejalan dengan pendapat Hamalik (Arsyad, 2011:2) bahwa media pembelajaran merupakan alat komunikasi untuk mengefektifkan proses belajar mengajar.

Kehidupan manusia sekaran di abad ke-21 mengalami perubahan-perubahan dari tata kehidupan abad sebelumnya. Pada Abad ke-21 ini sangat lekat dengan kemajuan teknologi yang memasuki berbagai aspek dalam kehidupan. Begitupun pendidikan juga ikut menerima dampak dari kemajuan teknologi tersebut. Bernie Trilling \& Charles Fadel dalam bukunya mengatakan “ achieving education's goals in our times is shaped by the increasingly powerful technologies we have for communicating, collaborating, and learning. And learning assumes a central role throughout life." Artinya untuk mencapai tujuan pendidikan di zaman sekarang dibantu teknologi yang semakin kuat untuk berkomunikasi, bekerja dan belajar.

Kemajuan teknologi dapat dimanfaatkan dalam berbagai unsur pendidikan. Baik pada perencanaan pembelajaran, media pembelajaran, dan bahkan sekarang pada kurikulum terbaru 
Jurnal Lebesgue : Jurnal Ilmiah Pendidikan Matematika, Matematika dan Statistika

Eka Kurnia

Volume 2, No. 2, Agustus 2021 hal.253-267

DOI Artikel : $10.46306 / \mathrm{lb} . \mathrm{v} 2 \mathrm{i} 2.39$

teknologi sangat berperan dalam proses pembuat laporan hasil belajar berupa raport karena raport tersebut telah dibuat berupa aplikasi raport. Kemudian Permainan edukatif dan animasi virtual merupakan dua contoh penerapan teknologi pada pembelajaran yang menarik perhatian peneliti untuk menggunakannya. Tidak dapat dipungkiri secara nyata kondisi saat ini membuktikan bahwa teknologi begitu bermanfaat ketika di tahun 2020 ini mengalami pandemik covid-19 pemerintah Indonesia menurunkan kebijakan pelaksanaan pendidikan daring. KEMENDIKBUD RI memerintahkan penyelenggaraan proses pembelajaran daring sesuai dengan Surat Edaran Mendikbud RI nomor 3 tahun 2020 tentang Pencegahan Corona Virus Disease (COVID-19) pada Satuan Pendidikan, dan Surat Sekjen Mendikbud nomor 35492/A.A5/HK/2020 tanggal 12 Maret 2020 perihal Pencegahan Penyebaran COVID-19. Teknologi menjadi solusi dari pemberlakuan pembelajaran secara daring.

Hal lainnya yaitu mengenai rata-rata usia anak di Indonesia masuk sekolah dasar pada usia 6 tahun, sehingga ketika anak berada di kelas IV SD merupakan "usia masa kanak-kanak akhir kisaran 10 s/d 12 tahun dimana usia tersebut memiliki karakteristik yang berbeda dengan anak-anak yang usianya lebih muda. Mereka senang bermain, senang bergerak dan melakukan sesuatu secara langsung." (Desmita, 2016:35) Sehingga dirasa pemilihan kelas IV untuk menjadi sampel penelitian cukup relevan dengan pendapat tersebut. Senada dengan hal tersebut Havighurts (Desmita, 2016:35) bahkan menyebutkan menguasai keterampilan yang diperlukan dalam permainan adalah salah satu tugas perkembangan anak sekolah dasar.”

Selain itu penelitian-penelitian terdahulu yang mendukung pertama penelitian karya Yulia Isratul Aini, PTP LPMP Bengkulu dengan judul " Pemanfaatan Media Pembelajaran Quizizz Untuk Pembelajaran Jenjang Pendidikan Dasar Dan Menengah Di Bengkulu" menunjukan hasil Media pembelajaran berupa Quizizz dapat dimanfaatkan sebagai salah satu alternatif media pembelajaran guna mencapai tujuan pembelajaran. (Aini, 2019). Penelitian lain dari Celine Jardinia Tanuwidjaja, Deny Tri Ardianto, Erandaru dengan penelitian berjudul " Perancangan Animasi Virtual Reality 'Slebor'Atau Ular Naga Sebagai Upaya Pelestarian Permainan Tradisional Di Indonesia" menunjukan hasil berdasarkan uji pemutaran video terhadap target audiens, menunjukan fakta dimana anak-anak sangat tertarik dengan animasi virtual 'Slebor' ini dan dapat langsung mengenal permainan tersebut karena mereka pada dasarnya telah mendapat materi tentang permainan. (Tanuwidjaja et al., 2019) .

Berdasarkan latar belakang maka peneliti tertarik melakukan penelitian yang menggunakan permainan edukatif dan animasi virtual serta bertujuan untuk membandingkan lebih bagus mana penggunaan permainan edukatif dengan animasi virtual untuk pembelajaran 
Jurnal Lebesgue : Jurnal Ilmiah Pendidikan Matematika, Matematika dan Statistika

Eka Kurnia

Volume 2, No. 2, Agustus 2021 hal.253-267

DOI Artikel : 10.46306/lb.v2i2.39

pada materi bangun datar.

\section{METODE PENELITIAN}

Penelitian ini tergolong penelitian yang menggunakan eksperimen semu (quasi eksperimen), yakni dilakukan dengan memberikan perlakuan kepada siswa pada penelitian kemudian memberikan tes. Penelitian ini dilakukan dengan eskperimen semukarena kelas yang digunakan telah terbentuk sebelumnya. Pada kedua kelas eksperimen diberikan perlakuan, hanya saja perlakuan yang diberikan itu berbeda. Adapun perlakuan pada kelas eksperimen A berupa permainan edukatif dan pada kelas eksperimen B berupa animasi virtual.

Kemudian dilaksanakan tes setelah pertemuan akhir dimana sudah diberi perlakuan pada masing-masing kelas. Desain penelitian telihat dalam tabel yang akan disajikan berikut:

Tabel 1. Desain Penelitian faktorial $2 \times 2$

\begin{tabular}{|c|c|c|c|c|}
\hline & \multicolumn{2}{|c|}{ Keaktifan Siswa (B) } & \multirow[t]{2}{*}{$\sum \mathbf{B}$} \\
\hline & & $\begin{array}{l}\text { Rendah } \\
\left(\mathrm{B}_{1}\right)\end{array}$ & Tinggi $\left(\mathrm{B}_{2}\right)$ & \\
\hline \multirow{3}{*}{$\begin{array}{c}\text { Media Pembelajaran } \\
\text { (A) }\end{array}$} & Permainan Edukatif $\left(\mathrm{A}_{1}\right)$ & $\mathrm{A}_{1} \mathrm{~B}_{1}$ & $\mathrm{~A}_{1} \mathrm{~B}_{2}$ & $\mathrm{~A}_{1}$ \\
\hline & Animasi Virtual $\left(\mathrm{A}_{2}\right)$ & $\mathrm{A}_{2} \mathrm{~B}_{1}$ & $\mathrm{~A}_{2} \mathrm{~B}_{2}$ & $\mathrm{~A}_{2}$ \\
\hline & $\sum \mathbf{K}$ & $\mathrm{B}_{1}$ & $\mathrm{~B}_{2}$ & \\
\hline
\end{tabular}

Keterangan:

A $\quad=$ Media Pembelajaran

B = Keaktifan Siswa

$\mathrm{A}_{1} \mathrm{~B}_{1}=$ Media permainan edukatif dengan keaktifan siswa kategori rendah

$\mathrm{A}_{1} \mathrm{~B}_{2}=$ Media permainan edukatif dengan keaktifan siswa kategori tinggi

$\mathrm{A}_{2} \mathrm{~B}_{1}=$ Media animasi virtual dengan keaktifan siswa kategori rendah

$\mathrm{A}_{2} \mathrm{~B}_{2}=$ Media animasi virtual dengan keaktifan siswa kategori tinggi

Selanjutnya adapun sampel dalam penelitian ini adalah siswa kelas IVA dan IVB. Adapun kelompok eksperimen A yaitu kelompok kelas IVA berjumlah 40 orang yang mendapat perlakuan penggunakan permainan edukatif, sedangkan kelompok eksperimen B yaitu kelompok kelas IVB berjumlah 40 orang yang mendapat perlakuan penggunaan animasi virtual. Jadi jumlah sampel yang digunakan adalah sebanyak 80 orang.

\section{HASIL DAN PEMBAHASAN}

Penelitian ini dilaksanakan di kelas IV yaitu kelas IVA dan IVB SDN Jatirangga I kota Bekasi. Penelitian kelas eksperimen A dilaksanakan di kelas IVA yang berjumlah 40 siswa, sedangkan penelitian kelas eksperimen B dilaksanakan di kelas IVB yang berjumlah 40 siswa. Hasil tes matematika pada kelas yang menggunakan media permainan edukatif memperoleh rentang skor antara 30 sampai 100 dengan jumlah 40 siswa. Rata-rata skor sebesar 73,75; nilai 
Jurnal Lebesgue : Jurnal Ilmiah Pendidikan Matematika, Matematika dan Statistika

Eka Kurnia

Volume 2, No. 2, Agustus 2021 hal.253-267

DOI Artikel : $10.46306 / \mathrm{lb} . \mathrm{v} 2 \mathrm{i} 2.39$

modus 65; nilai median 70; serta standar deviasi 17,09.

Tabel 10. Distribusi Frekuensi Hasil Belajar Matematika Pada Permainan Edukatif

\begin{tabular}{|c|c|c|c|c|c|c|}
\hline \multirow{2}{*}{ No } & Kelas & Nilai & BK & \multicolumn{3}{|c|}{ Frekuensi } \\
\cline { 5 - 7 } & Interval & Tengah & & Absolu & Kumulatif & Relatif \\
& & & & & & \\
\hline 1 & $30-42$ & 36 & $29,5-42,5$ & 2 & 2 & 5,00 \\
\hline 2 & $43-55$ & 49 & $42,5-55,5$ & 4 & 6 & 10,00 \\
\hline 3 & $56-68$ & 62 & $55,5-68,5$ & 9 & 15 & 22,50 \\
\hline 4 & $69-81$ & 75 & $68,5-81,5$ & 12 & 27 & 30,00 \\
\hline 5 & $82-94$ & 88 & $81,5-94,5$ & 5 & 32 & 12,50 \\
\hline 6 & $95-107$ & 101 & $94,5-107,5$ & 8 & 40 & 20,00 \\
\hline \multicolumn{2}{|r|}{ Jumlah } & & 40 & & & 100 \\
\hline
\end{tabular}

Berdasarkan tabel dibuat histogram dan poligon hasil belajar matematika siswa kelas yang menggunakan media permainan edukatif berikut:

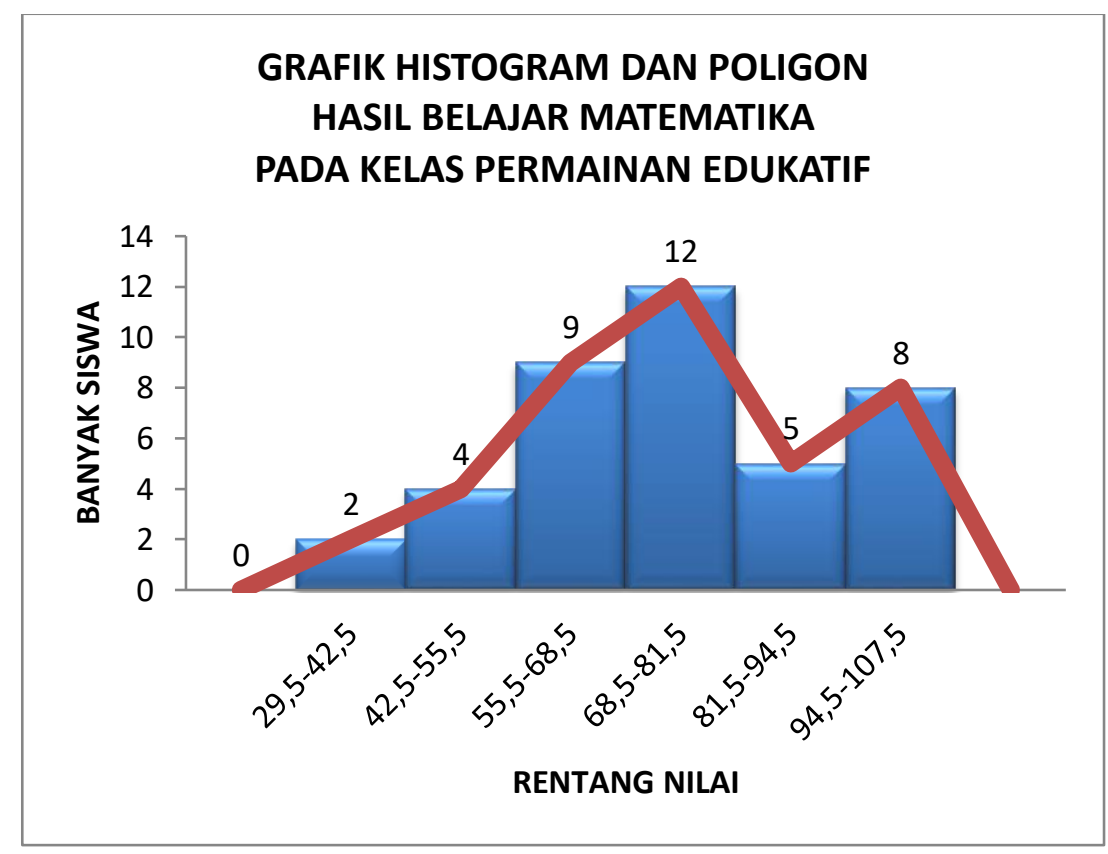

Gambar 1. Grafik histogram dan poligon hasil belajar matematika kelas permainan edukatif

Dari grafik dan tabel distribusi frekuensi hasil belajar matematika di atas terlihat sebagian besar siswa memperoleh skor antara 68,5-81,5 sebanyak 12 siswa atau sebesar 30\%, kemudian skor antara 55,5-68,5 sebanyak 9 siswa atau sebesar 22,50\%, skor 94,5-107,5 sebanyak 8 siswa atau sebesar $20 \%$, skor $81,5-94,5$ sebanyak 5 siswa atau sebesar $12,50 \%$, skor $42,5-55-5$ sebanyak 4 siswa atau sebesar 10\%, sedangkan skor terendah 29,5-42,5 sebanyak 2 siswa atau 
Jurnal Lebesgue : Jurnal Ilmiah Pendidikan Matematika, Matematika dan Statistika

Eka Kurnia

Volume 2, No. 2, Agustus 2021 hal.253-267

DOI Artikel : 10.46306/lb.v2i2.39

sebesar $5 \%$.

Hasil belajar matematika pada kelas yang menggunakan media animasi virtual, diperoleh rentang skor antara 15 sampai 100 dengan jumlah 40 siswa. Dengan rata-rata skor sebesar 61,12; nilai modus 90; nilai median 57,5; serta standar deviasi 25,13.

Tabel 11 Distribusi Frekuensi Hasil Belajar Matematika Kelas Animasi Virtual

\begin{tabular}{|c|c|c|c|c|c|c|}
\hline No & Kelas & Nilai & BK & \multicolumn{3}{|c|}{ Frekuensi } \\
\cline { 5 - 7 } & Interval & Tengah & & Absolu & Kumulatif & Relatif \\
& & & & 1 & & \\
\hline 1 & $15-30$ & 22,5 & $14,5-30,5$ & 6 & 6 & 15,00 \\
\hline 2 & $31-46$ & 38,5 & $30,5-46,5$ & 10 & 16 & 25,00 \\
\hline 3 & $47-62$ & 54,5 & $46,5-62,5$ & 5 & 21 & 12,50 \\
\hline 4 & $63-78$ & 70,5 & $62,5-78,5$ & 7 & 28 & 17,50 \\
\hline 5 & $79-94$ & 86,5 & $78,5-94,5$ & 7 & 35 & 17,50 \\
\hline 6 & $95-110$ & 102,5 & $94,5-109,5$ & 5 & 40 & 12,50 \\
\hline & & & & 40 & & 100 \\
\hline
\end{tabular}

Berdasarkan tabel distribusi tersebut dapat dibuat histogram dan poligon pada gambar berikut:

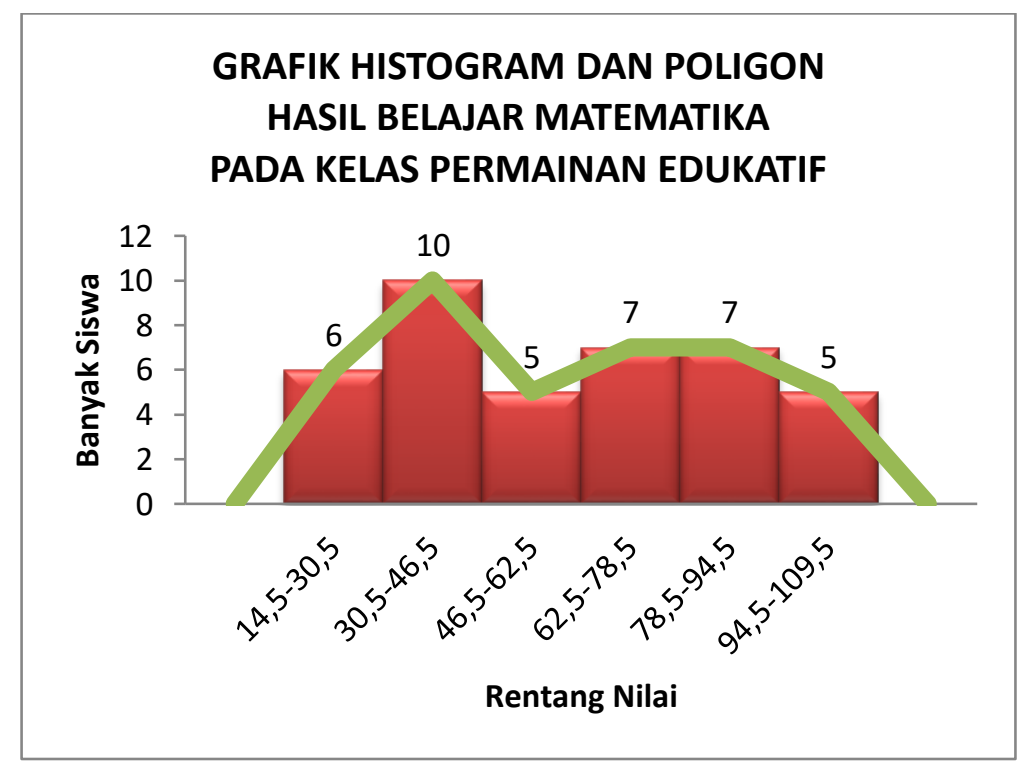

Gambar 2. Grafik histogram dan poligon hasil belajar kelas animasi virtual

Dari grafik dan tabel distribusi frekuensi di atas terlihat mayoritas siswa memperoleh skor 30,5 - 46,5 sebanyak 10 siswa atau sebesar $25 \%$ skor 62,5 - 78,5 sebanyak 7 siswa atau sebesar $17,50 \%$, skor 78,5 - 94,5 sebanyak 7 siswa atau sebesar 17,50\%, skor 46,5-62,5 sebanyak 5 siswa atau sebesar 12,50\% skor 94,5-109,5 sebanyak 5 siswa atau sebesar 12,50\%, 
Jurnal Lebesgue : Jurnal Ilmiah Pendidikan Matematika, Matematika dan Statistika

Eka Kurnia

Volume 2, No. 2, Agustus 2021 hal.253-267

DOI Artikel : 10.46306/lb.v2i2.39

sedangkan skor terendah 14,5-30,5 sebanyak 6 siswa atau sebesar $15 \%$.

Untuk dapat menguji hipotesis, peneliti menggunakan analisis varian dua jalur yang disajikan pada tabel di bawah ini:

Tabel 14. Uji Hipotesis

\begin{tabular}{|c|c|c|c|c|c|}
\hline \multirow[t]{2}{*}{ Sumber Varians } & \multirow[t]{2}{*}{$\mathrm{db}$} & \multirow[t]{2}{*}{ JK } & \multirow{2}{*}{$\begin{array}{l}\text { RJK } \\
\left(s^{2}\right)\end{array}$} & \multirow[t]{2}{*}{$F_{h}$} & $F_{\text {tabel }}$ \\
\hline & & & & & 0,05 \\
\hline Antar Kolom (Ak) & 1 & 3251,25 & 3251,2 & 8,09 & \multirow{6}{*}{3,96} \\
\hline & & & 5 & & \\
\hline Antar Baris (Ab) & 1 & 3781,25 & 3781,2 & 9,41 & \\
\hline & & & 5 & & \\
\hline Interaksi (I) & 1 & 1620,00 & 1620,0 & 4,03 & \\
\hline & & & 0 & & \\
\hline \multirow[t]{2}{*}{ Antar Kelompok (A) } & \multirow[t]{2}{*}{3} & \multirow[t]{2}{*}{8652,50} & 2884,1 & 7,18 & \multirow[t]{2}{*}{2,72} \\
\hline & & & 7 & & \\
\hline Dalam Kelompok (D) & 76 & 30527,50 & 401,68 & - & - \\
\hline Total di Reduksi (TR) & 79 & 39180,00 & 495,95 & - & - \\
\hline Rerata/ Koreksi (R) & 1 & 369920,00 & 369920 & - & - \\
\hline & & &, 00 & & \\
\hline Total (T) & 80 & 407150 & - & - & - \\
\hline
\end{tabular}

Dari tabel diatas dapat disimpulkan Pertama, diperoleh nilai signifikan pada sumber varians Antar Kolom (AK) yang digunakan untuk menguji Hipotesis 1, diperoleh $\mathrm{F}_{\text {hitung }}=8,09$ dan $\mathrm{F}_{\text {tabel }}=3,96$ dengan $\mathrm{db}$ pembilang $=1$, db penyebut $=79$ dan taraf signifikan $=0,05$. Kriteria pengujian hipotesis, jika $\mathrm{F}_{\text {hitung }}>\mathrm{F}_{\text {tabel }}$ maka $\mathrm{H}_{\mathrm{o}}$ ditolak. Jika dibandingkan $\mathrm{F}_{\text {hitung }}$ yang diperoleh dengan $\mathrm{F}_{\text {tabel }}$ maka, diperoleh kesimpulan 8,09 > 3,96 atau $\mathrm{F}_{\text {hitung }}>\mathrm{F}_{\text {tabel }}$ maka $\mathrm{H}_{\mathrm{o}}$ ditolak artinya terdapat perbedaan hasil belajar matematika pada kelas yang menggunakan media permainan edukatif dan media animasi virtual.

Kedua, diperoleh nilai signifikan pada sumber varians Antar Baris (AB) yang digunakan untuk menguji Hipotesis 2, diperoleh $\mathrm{F}_{\text {hitung }}=9,41$ dan $\mathrm{F}_{\text {tabel }}=3,96$ dengan db pembilang $=1$, $\mathrm{db}$ penyebut $=79$ dan taraf signifikan $=0,05$. Kriteria pengujian hipotesis, jika $F_{\text {hitung }}>F_{\text {tabel }}$ maka Ho ditolak. Jika dibandingkan $F_{\text {hitung }}$ yang diperoleh dengan $F_{\text {tabel }}$ maka, diperoleh kesimpulan 9,41 > 3,96 atau $\mathrm{F}_{\text {hitung }}>\mathrm{Ft}_{\mathrm{abel}}$ maka $\mathrm{H}_{\mathrm{o}}$ ditolak artinya terdapat perbedaan hasil belajar matematika pada keaktifan siswa kategori rendah dan kategori tinggi. 
Jurnal Lebesgue : Jurnal Ilmiah Pendidikan Matematika, Matematika dan Statistika

Eka Kurnia

Volume 2, No. 2, Agustus 2021 hal.253-267

DOI Artikel : $10.46306 / \mathrm{lb} . \mathrm{v} 2 \mathrm{i} 2.39$

Ketiga, diperoleh nilai signifikan pada sumber varians Interaksi (I) yang digunakan untuk menguji Hipotesis 3, diperoleh $F_{\text {hitung }}=4,03$ dan $F_{\text {tabel }}=3,96$ dengan $\mathrm{db}$ pembilang $=1 \mathrm{db}$ penyebut $=79$ dan taraf signifikan $=0,05$. Kriteria pengujian hipotesis, jika $F_{\text {hitung }}>F_{\text {tabel }}$ maka Ho ditolak. Jika dibandingkan $F_{\text {hitung }}$ yang diperoleh dengan $F_{\text {tabel }}$ maka, diperoleh kesimpulan 4,03 > 3,96 atau $\mathrm{F}_{\text {hitung }}>\mathrm{Ft}_{\text {abel }}$ maka $\mathrm{H}_{\mathrm{o}}$ ditolak artinya terdapat interaksi antara media pembelajaran dan keaktifan siswa terhadap hasil belajar matematika.

Setelah diketahui terdapat interaksi yang signifikan maka selanjutnya dilakukan uji lanjut Tukey dengan memperhatikan data-data yang telah diperoleh sebelumnya untuk membuktikan hipotesis keempat dan hipotesis kelima. Adapun hasil uji lanjut tukey untuk menguji Hipotesis 4 , yaitu $Q_{\text {hitung }}=\frac{72,00-50,25}{\sqrt{\frac{401,68}{20}}}=4,85$ sedangkan pada $\alpha 0,05 \mathrm{db} \mathrm{v}_{\mathrm{v} 1}=4$ dan $\mathrm{db}_{\mathrm{v} 2}=20$ menunjukan $\mathrm{Q}_{\text {tabel }}=3,96$. Kriteria pengujian hipotesis, jika $\mathrm{Q}_{\text {hitung }}>\mathrm{Q}_{\text {tabel }}$ maka Ho ditolak. Jika dibandingkan Qhitung yang diperoleh dengan $\mathrm{Q}_{\text {tabel }}$ maka, diperoleh kesimpulan 4,85 > 3,96 atau $\mathrm{Q}_{\text {hitung }}>\mathrm{Qt}_{\mathrm{abel}}$ maka $\mathrm{H}_{\mathrm{o}}$ ditolak artinya terdapat perbedaan hasil belajar matematika menggunakan permainan edukatif dan animasi virtual pada keaktifan siswa kategori rendah.

Berikutnya hasil uji lanjut tukey untuk menguji Hipotesis 5, yaitu $Q_{\text {hitung }}=\frac{76,75-73,00}{\sqrt{\frac{401,68}{20}}}=$ 0,84 sedangkan pada $\alpha 0,05 \mathrm{db}_{\mathrm{v} 1}=4$ dan $\mathrm{db}_{\mathrm{v} 2}=20$ menunjukan $\mathrm{Q}_{\text {tabel }}=3,96$. Kriteria jika $\mathrm{Q}_{\text {hitung }}$ $>\mathrm{Q}_{\text {tabel }}$ maka Ho ditolak. Jika dibandingkan $\mathrm{Q}_{\text {hitung }}$ yang diperoleh dengan $\mathrm{Q}_{\text {tabel }}$ maka, diperoleh kesimpulan 0,84 $<3,96$ atau $\mathrm{Q}_{\text {hitung }}<\mathrm{Qt}_{\text {abel }}$ maka $\mathrm{H}_{\mathrm{o}}$ diterima artinya tidak terdapat perbedaan hasil belajar matematika menggunakan permainan edukatif dan animasi virtual pada keaktifan siswa kategori tinggi.

Data rata-rata hasil belajar matematika di kelas yang menggunakan media permainan edukatif sebesar 72,00 pada keaktifan siswa kategori rendah dan sebesar 76,75 pada keaktifan siswa kategori tinggi. Selanjutnya di kelas yang menggunakan media animasi virtual sebesar 50,25 pada keaktifan siswa kategori rendah dan sebesar 73,00 pada keaktifan siswa kategori tinggi. Telihat bahwa terdapat perbedaan hasil belajar matematika pada penggunaan media permainan edukatif dan media animasi virtual yaitu dengan selisih 21,75 pada keaktifan siswa kategori rendah hasil belajar matematika dengan menggunakan media permainan edukatif lebih baik dan pada keaktifan siswa kategori tinggi yaitu selisih 3,75 penggunaan peramainan edukatif juga menunjukan hasil belajar matematika lebih baik. Hal ini menunjukan bahwa media permainan edukatif dan media animasi virtrual mempengaruhi hasil belajar matematika pada keaktifan siswa.Terjadinya perbedaan hasil belajar matematika siswa karena perlakuan 
berbeda yaitu pada kelas eksperimen A menggunakan media permainan edukatif dan pada kelas eksperimen B menggunakan media animasi virtual.

Beberapa hal peneliti temukan dilapangan ketika menggunakan media permainan edukatif pada kelas eksperimen A, walaupun siswa terbiasa menggunakan permainan dengan gawai, namun media ini berbeda dengan penggunaan gawai seperti yang biasa. Pada pembelajaran menggunakan media permainan edukatif ini siswa sangat antusias dikarenakan pada saat pembelajaran siswa tidak terlalu bergantung dengan guru dan akan menambah rasa kepercayaan dengan kemampuan diri untuk melakukan permainan edukatif sendiri, pemberian soal latihan sebagai bentuk tantangan untuk belajar membuat pembelajaran semakin menarik. Sedangkan pada kelas eksperimen B yang menggunakan media animasi virtual kurang dapat mengoptimalkan partisipasi siswa dalam mengeluarkan pendapat atau pertanyaan saat pembelajaran karena media animasi saat digunakan tidak dapat dijeda. Dengan demikan dapat disimpulkan penggunaan media permainan edukatif dan media animasi virtual memberikan hasil belajar matematika yang berbeda pada kedua kelas eksperimen, sehingga asumsi hasil belajar matematika akan tercapai maksimal ketika perlakuan-perlakuan dalam pembelajaran disesuaikan sedemikian rupa dengan perbedaan kemampuan siswa.

Selanjutnya untuk mengetahui bagaimana perbandingan hasil belajar matematika siswa melalui uji normalitas, uji homogenitas dan juga uji hipotesis dimana pada penelitian ini menggunakan uji ANAVA dua jalur. Berdasarkan hasil analisis prasayarat yang dilakukan sebelum pengujian hipotesis didapatkan hasil perhitungan uji normalitas di kelas yang menggunakan media permainan edukatif diperoleh $\mathrm{X}^{2}$ hitung $=7,69$ dan di kelas yang menggunakan media animasi virtual diperoleh $X^{2}$ hitung $=7,23$. Jika $X^{2}$ hitung pada semua kemampuan siswa dibandingkan dengan $\mathrm{X}^{2}$ tabel yang memiliki nilai $\mathrm{n}=40, \mathrm{dk}=5$ dan taraf siginifikansi $\alpha=0,05$ diperoleh $\mathrm{X}_{\text {tabel }}^{2}=11,070$. Maka, keseluruhan data pada kemampuan siswa mendapatkan kriteria $\mathrm{X}^{2}{ }_{\text {hitung }}<\mathrm{X}_{\text {tabel }}^{2}$ dapat disimpulkan $\mathrm{H}_{\mathrm{o}}$ diterima, artinya bahwa seluruh sampel berdistribusi normal.

Kemudian hasil pengujian uji homogenitas, diperoleh $\mathrm{X}^{2}$ hitung $=4,43$ pada keseluruhan kelas data, Dengan kriteria: $\mathrm{dk}=4-1=3$, dan taraf signifikan $\alpha=0,05$ diperoleh $\mathrm{X}_{\text {tabel }}^{2}=$ 7,81. Maka, $X^{2}$ hitung $<X^{2}$ tabel $h_{o}$ diterima artinya kelompok memiliki varian yang sama atau bersifat homogen.

Setelah melakukan uji prasyarat, peneliti melakukan uji analisis data perhitungan dan pengujian hipotesis. Uji hipotesis ANAVA dua jalur menunjukan bahwa: Pertama, diperoleh nilai signifikan pada sumber varians Antar Kolom (AK) yang digunakan untuk menguji 
Hipotesis 1, diperoleh $\mathrm{F}_{\text {hitung }}=8,09$ dan $\mathrm{F}_{\text {tabel }}=3,96$ dengan $\mathrm{db}$ pembilang $=1$, db penyebut $=$ 79 dan taraf signifikan $=0,05$. Jika $F_{\text {hitung }}>F_{\text {tabel }}$ maka $H_{o}$ ditolak. Jika dibandingkan $F_{\text {hitung }}$ yang diperoleh dengan $F_{\text {tabel }}$ maka, diperoleh kesimpulan 8,09 $>3,96$ atau $F_{\text {hitung }}>F_{\text {tabel }}$ maka $\mathrm{H}_{\mathrm{o}}$ ditolak artinya terdapat perbedaan hasil belajar matematika yang menggunakan media permainan edukatif dan media animasi virtual. Kesimpulan ini menunjukan bukti bahwa hasil belajar matematika dipengaruhi oleh media pembelajaran yang digunakan.

Kedua, diperoleh nilai signifikan pada sumber varians Antar Baris (AB) yang digunakan untuk menguji Hipotesis 2, diperoleh $F_{\text {hitung }}=9,41$ dan $F_{\text {tabel }}=3,96$ dengan db pembilang $=1$, $\mathrm{db}$ penyebut $=79$ dan taraf signifikan $=0,05$. Kriteria pengujian hipotesis, jika $F_{\text {hitung }}>F_{\text {tabel }}$ maka Ho ditolak. Jika dibandingkan $F_{\text {hitung }}$ yang diperoleh dengan $F_{\text {tabel }}$ maka, diperoleh kesimpulan 9,41 > 3,96 atau $\mathrm{F}_{\text {hitung }}>\mathrm{Ft}_{\mathrm{abel}}$ maka $\mathrm{H}_{\mathrm{o}}$ ditolak artinya terdapat perbedaan hasil belajar matematika pada keaktifan siswa kategori rendah dan kategori tinggi. Kesimpulan ini menunjukan bukti bahwa terdapat pengaruh yang signifikan dari keaktifan siswa terhadap hasil belajar matematika.

Ketiga, diperoleh nilai signifikan pada sumber varians Interaksi (I) yang digunakan untuk menguji Hipotesis 3, diperoleh $F_{\text {hitung }}=4,03$ dan $F_{\text {tabel }}=3,96$ dengan db pembilang $=1$, db penyebut $=79$ dan taraf signifikan $=0,05$. Kriteria pengujian hipotesis, , jika $F_{\text {hitung }}>F_{\text {tabel }}$ maka Ho ditolak. Jika dibandingkan $F_{\text {hitung }}$ yang diperoleh dengan $F_{\text {tabel }}$ maka, diperoleh kesimpulan 4,03 > 3,96 atau $\mathrm{F}_{\text {hitung }}>\mathrm{Ft}_{\text {abel }}$ maka $\mathrm{H}_{\mathrm{o}}$ ditolak artinya terdapat interaksi antara media pembelajaran dengan keaktifan siswa terhadap hasil belajar matematika. Kesimpulan ini menunjukan bukti bahwa penggunaan media pada siswa yang memiliki keaktifan kategori tinggi memiliki hasil belajar matematika yang tinggi pula. Begitupun sebaliknya pada penerapan kedua media pembelajaran ini pada siswa yang memiliki keaktifan kategori rendah memiliki hasil belajar matematika yang rendah pula. Artinya hasil belajar matematika baik pada penggunaan media permainan edukatif dan media animasi virtual sama-sama dipengaruhi oleh keaktifan siswa.

Ketiga hipotesis ini menunjukkan bahwa hasil belajar matematika dipengaruhi oleh media pembelajaran yang digunakan. Begitupun keaktifan siswa mempengaruhi hasil belajar matematika dan hasil belajar matematika pada media permainan edukatif dan animasi virtual sama-sama dipengaruhi oleh keaktifan siswa. Kesimpulannya terdapat perbedaaan rata-rata hasil belajar matematika siswa dengan menggunakan media permainan edukatif dan animasi virtual ditinjau dari keaktifan siswa. Artinya terdapat perbedaan rata-rata antara hasil belajar matematika dan media pembelajaran kemudian antara hasil belajar matematika dan keaktifan 
siswa dan antara interaksi media pembelajaran dan keaktifan siswa. Terlihat dari rata-rata hasil belajar media permainan edukatif lebih tinggi daripada media animasi virtual ditinjau dari keaktifan siswa. Sejalan dengan pendapat yang menyatakan "banyak permaianan yang mengandung aktivitas yang merupakan faktor pendorong perkembangan kognitif, fisik dan sosial" (Papalia:387). Hasil belajar matematika merupakan salah satu bentuk yang melibatkan kognitif berarti bisa dipengaruhi oleh kegiatan permainan pula. Hal senada ditunjukan oleh penelitian Agung Setiawan, dkk yang ada pada penelitian relevan berjudul "Implementasi Media Games Edukasi Quizizz untuk Meningkatkan Hasil Belajar Matematika" dengan hasil adanya peningkatan yang signifikan sehingga membuktikan bahwa permainan edukatif memang berpengaruh pada hasil belajar matematika.

Setelah diketahui terdapat interaksi yang signifikan maka dilakukan uji lanjut Tukey dengan memperhatikan data-data yang telah diperoleh sebelumnya untuk membuktikan hipotesis keempat dan hipotesis kelima. Adapun hasil uji lanjut tukey untuk menguji Hipotesis 4, yaitu Qhitung $=4,85$ sedangkan pada $\alpha 0,05 \mathrm{db}_{\mathrm{v} 1}=4$ dan $\mathrm{db}_{\mathrm{v} 2}=20$ menunjukan $\mathrm{Q}_{\text {tabel }}=3,96$. Kriteria pengujian hipotesis, jika $Q_{\text {hitung }}>Q_{\text {tabel }}$ maka Ho ditolak. Jika dibandingkan $Q_{\text {hitung yang }}$ diperoleh dengan $\mathrm{Q}_{\text {tabel }}$ maka, diperoleh kesimpulan 4,85 > 3,96 atau $\mathrm{Qhitung}_{\mathrm{P}}>\mathrm{Qt}_{\text {abel }}$ maka $\mathrm{H}_{\mathrm{o}}$ ditolak artinya terdapat perbedaan hasil belajar matematika menggunakan permainan edukatif dan animasi virtual pada keaktifan siswa kategori rendah. Berikutnya hasil uji lanjut tukey untuk menguji Hipotesis 5, yaitu Qhitung $=0,84$ sedangkan pada $\alpha 0,05 \mathrm{db}_{\mathrm{v} 1}=4 \mathrm{dan}_{\mathrm{db}_{\mathrm{v} 2}=20}$ menunjukan $\mathrm{Q}_{\text {tabel }}=3,96$. Kriteria pengujian hipotesis, jika $\mathrm{Q}_{\text {hitung }}>\mathrm{Q}_{\text {tabel }}$ maka Ho ditolak. Jika

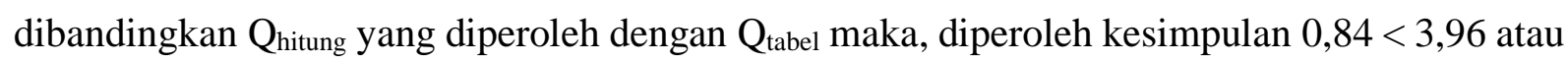
Qhitung $<\mathrm{Qt}_{\mathrm{abel}}$ maka $\mathrm{H}_{\mathrm{o}}$ diterima artinya tidak terdapat perbedaan hasil belajar matematika menggunakan permainan edukatif dan animasi virtual pada keaktifan siswa kategori tinggi.

\section{KESIMPULAN}

Berdasarkan hasil analisis data yang telah dilakukan dapat disimpulkan terdapat perbedaaan rata-rata hasil belajar matematika siswa dengan menggunakan media permainan edukatif dan animasi virtual ditinjau dari keaktifan siswa. Artinya terdapat perbedaan rata-rata antara hasil belajar matematika dan media pembelajaran kemudian antara hasil belajar matematika dan keaktifan siswa dan antara interaksi media pembelajaran dan keaktifan siswa. Terlihat dari rata-rata hasil belajar media permainan edukatif lebih tinggi daripada media animasi virtual ditinjau dari keaktifan siswa.

Setelah adanya interaksi yang signifikan maka dilakukan uji lanjut Tukey yang membuktikan terdapat perbedaan rata-rata hasil belajar matematika menggunakan media 
permainan edukatif dan animasi virtual pada keaktifan siswa kategori rendah sedangkan pada keaktifan siswa kategori tinggi terbukti tidak ada perbedaan rata-rata hasil belajar matematika menggunakan permainan edukatif dan animasi virtual.

Sejalan dengan pendapat yang menyatakan "banyak permaianan yang mengandung aktivitas yang merupakan faktor pendorong perkembangan kognitif, fisik dan sosial" (Papalia:387). Hasil belajar matematika merupakan salah satu bentuk yang melibatkan kognitif berarti bisa dipengaruhi oleh kegiatan permainan pula. Hal senada ditunjukan oleh penelitian Agung Setiawan, dkk yang ada pada penelitian relevan berjudul "Implementasi Media Games Edukasi Quizizz untuk Meningkatkan Hasil Belajar Matematika" dengan hasil adanya peningkatan yang signifikan sehingga membuktikan bahwa permainan edukatif memang berpengaruh pada hasil belajar matematika.

Berikut beberapa saran dari peneliti diantaranya :

1. Bagi guru semoga dapat membuat dan mengembangkan rencana pembelajaran yang dapat menarik dalam belajar matematika misalnya melakukan kegiatan pembelajaran dalam bentuk penguasaan model pembelajaran sehingga dapat membangkitkan keaktifan dan perhatian siswa dalam belajar.

2. Bagi peneliti yang ingin melakukan penelitian yang sama, yaitu menggunakan permaanan edukatif dan animasi virtual diharapkan dapat lebih teliti dalam mengatur waktu untuk setiap tahapan dalam pembelajaran sehingga penelitian dapat dilaksanakan dengan baik.

3. Bagi Kepada kepala sekolah sebagai pemilik kebijakan dalam mengambil keputusan diharapkan lebih memperhatikan penyediaan fasilita dalam proses pembelajaran.

4. Hasil penelitian ini masih sangat sederhana, apa yang didapat dari hasil penelitian ini bukan merupakan hasil akhir, tentu segala keterbatasan yang ada dalam penelitian ini dapat dijadikan bahan referensi untuk penelitian lebih lanjut dengan menggunakan permainan edukatif dan animasi virtual.

\section{DAFTAR PUSTAKA}

Abdullah, Ridwan. 2014. Inovasi Pembelajaran.Jakarta:Bumi aksara.

Adianto, S. (2020). Penerapan Scientific Dan Cooperative Learning Dengan Quis Online Untuk Meningkatkan Hasil Belajar Siswa Sekolah Dasar. 7(1), 57-65. https://doi.org/10.17977/um031v7i12020p057

Agustien, R., \& Umamah, N. (2018). Pengembangan Media Pembelajaran Video Animasi Dua Dimensi Situs Pekauman di Bondowoso Dengan Model Addie Mata Pelajaran Sejarah Kelas X IPS ( The Development of Two Dimensional Animation Video of Pekauman Website as Instructional Media With Addie Model in. 19-23.

Aini, Y. I. (2019). Pemanfaatan Media Pembelajaran Quizizz Untuk Pembelajaran Jenjang Pendidikan Dasar Dan Menengah Di Bengkulu. Jurnal Kependidikan, 2(25), 1-6. 
Akhsanti, D. (2019). Keefektifan media animasi terhadap motivasi dan hasil belajar matematika kelas iv sekolah dasar negeri 1 jambudesa kabupaten purbalingga.

Aljuhani, K., Sonbul, M., Althabiti, M., \& Meccawy, M. (2018). Creating a Virtual Science Lab (VSL): the adoption of virtual labs in Saudi schools. Smart Learning Environments, 5(1). https://doi.org/10.1186/s40561-018-0067-9

Anna, dkk. 2012. Sekolah yang Menyenangkan:Metode Kreatif Mengajar dan Pengembangan Karakter Siswa. Bandung: Nuansa.

Arsyad, Azhar. 2011. Media Pembelajaran. Jakarta: Raja Grafindo Persada.

Desmita. 2016. Psikologi PerkembanganPeserta Didik. Bandung: Remaja Rosdakarya.

Firmansyah, D. (2013). Strategi Pembelajaran Dan Minat Belajar Terhadap Hasil Belajar Matematika. Jurnal Teknologi Pendidikan (JTP), 6(2), 34-44. https://doi.org/10.24114/jtp.v6i2.4996

Gunawan, F. I., \& Sunarman, S. G. (n.d.). Pengembangan Kelas Virtual Dengan Google Classroom Dalam Keterampilan Pemecahan Masalah ( Problem Solving ) Topik Vektor Pada Siswa Smk.

Hamka. 2015. Tafsir Al Azhar. Jilid 5. Depok: Gema Insani.

Hariyanto, Warsono. 2012. Pembelajran Aktif. Bandung: Remaja Rosdakarya.

Heruman. 2010. Model Pembelajaran Matematika. Bandung: Rosdakarya.

Jihad, Asep. Abdul. 2012. Evaluasi Pembelajaran. Yogyakarta: Multi Presindo.

Julaeha, S. (2011). Virtual Learning: Pemanfaatan Teknologi Informasi Dan Komunikasi Untuk

Meningkatkan Kualitas Pembelajaran. Virtual Learning: Pemanfaatan Teknologi

Informasi Dan Komunikasi Untuk Meningkatkan Kualitas Pembelajaran.

Kasmadi., Nia.S,S. 2014. Panduan Modern Penelitian Kuantitatif. Bandung: Alfabeta.

Khuluqo,E,Ihsana. 2016. Belajar dan Pembelajaran Konsep Dasar Metode dan Aplikasi

Nilai-Nilai Spiritualitas dalam Proses Pembelajaran. Yogyakarta: Pustaka Pelajar.

Kusdiwelirawan, Acep. 2014. Statistika Pendidikan. Jakarta: Uhamka Press.

Marno., Idrus.2014. Strategi, Metode dan Teknik Mengajar. Jakarta: A-Ruzz Media.

Munadi, Yudhi. 2010. Media Pembelajaran. Jakarta: Gaung Persada Press.

Nurhayat, E. (2020). Meningkatkan Keaktifan Siswa Dalam Pembelajaran Daring Melalui Media Game Edukasi Quiziz pada Masa Pencegahan Penyebaran Covid-19. 3(3), 36-40.

Papalia, E.D., dkk. 2018. Human Development (Psikologi Perkembangan Bagian I s/d IV)"'. Jakarta: Kencana Prenada Media Group.

Peraturan Mentri Republik Indonesia nomor 3 tahun 2020 tentang Pencegahan Corona Virus Disease (COVID-19) pada Satuan Pendidikan.

Pertiwi, M. S., Sanubari, T. P. E., \& Putra, K. P. (2018). Gambaran Perilaku Penggunaan Gawai dan Kesehatan Mata Pada Anak Usia 10-12 Tahun. Jurnal Keperawatan Muhammadiyah, 3(1), 28-34. https://doi.org/10.30651/jkm.v3i1.1451

Pitoyo, M. D., Sumardi, S., \& Asib, A. (2019). Gamification based assessment: A Test Anxiety Reduction through Game Elements in Quizizz Platform. International Online Journal of Education and Teaching (IOJET), 6(3), 456-471. http://iojet.org/index.php/IOJET/article/view/626

Purba, L. S. L. (2019). Peningkatan Konsentrasi Belajar Mahasiswa Melalui Pemanfaatan Evaluasi Pembelajaran Quizizz Pada Mata Kuliah Kimia Fisika I. Jurnal Dinamika Pendidikan. https://doi.org/10.33541/jdp.v12i1.1028

Purwanto. (2011). Evaluasi Hasil Belajar. Pustaka Pelajar.

Putri, M. P., Prestiliano, J., \& Setiyanti, A. A. (2014). Perancangan Media Pembelajaran Matematika Volume Bangun Ruang Kelas VI SD Menggunakan Teknologi Augmented Reality Dan Animasi 3D Pada Android.

Randi, A. (2017). Pemanfaatan Teknologi Virtual Reality Sebagai Media Pembelajaran 
Interaktif Untuk Sistem Tata Surya Berbasis Android.

Rifa, Iva. 2012. Koleksi Games Edukatif di Dalam dan Luar Sekolah. Yogjakarta: Flash Books.

Rusman. K.,Deni. R.,Cepi. 2011. Pembelajaran Berbasis Teknologi Informasi dan Komunikasi. Jakarta: Rajagrafindo Persada.

Sabani, N., Komunikasi, D. I., \& Indonesia, U. (2018). Generasi milenial dan absurditas debat kusir virtual. 48(1), 95-108.

Setiawan, A., Wigati, S., \& Sulistyaningsih, D. (2019). Implementasi Media Game Edukasi Quizizz Untuk Meningkatkan Hasil Belajar Matematika Materi Sistem Persamaan Linear Tiga Variabel Kelas X Ipa 7 Sma Negeri 15 Semarang Tahun Pelajaran 2019 / 2020. Seminar Nasional Edusainstek FMIPA UNIMUS 2019 ISBN, ISBN 2685-, 167-173.

Setyosari, Punaji. 2013. Metode Penelitian Pendidikan Dan Pengembangan. Jakarta: Prenamedia.

Sri Ariyati, T. M. (2016). Perancangan animasi interaktif pembelajaran asmaul husna. II(1), $116-121$.

Sugianto, D., Abdullah, A. G., Elvyanti, S., \& Muladi, Y. (2013). Modul Virtual : Multimedia Flipbook Dasar Teknik Digital. Ix(2), 101-116.

Sugiyono. 2011. Statistika Untuk Penelitian. Bandung: Alfabeta.

Sugiyono. 2016. Metode Penelitian Kuantitatif, Kualitatif dan R \& D. Bandung: Alfabeta.

Suni Astini, N. K. (2020). Tantangan Dan Peluang Pemanfaatan Teknologi Informasi Dalam

Pembelajaran Online Masa Covid-19. Cetta: Jurnal Ilmu Pendidikan, 3(2), 241-255. https://doi.org/10.37329/cetta.v3i2.452

Supardi. 2016. Aplikasi Statistik dalam Penelitian Konsep Statistik yang Lebih Komprehensif. Jakarta: Change Publication.

Susilo, A., \& U.S., S. (2015). Penerapan Model Pembelajaran Team Assisted Individualization Berbantuan Lembar Kerja Siswa dalam Upaya Meningkatkan Kualitas Proses dan Hasil Belajar Matematika Siswa MTs. Formatif: Jurnal Ilmiah Pendidikan MIPA, 1(3), 192207. https://doi.org/10.30998/formatif.v1i3.78

Syahrir, A. S., \& Oktavianus, M. (2016). Visualisasi Susunan Rangka Manusia Berbasis Augmented Reality untuk Mata Pelajaran IPA pada SD Negeri Tamalanrea 2 Makassar. Prosiding Seminar Ilmiah Sistem Informasi Dan Teknologi Informasi, V(2), 1-10.

Syifa, L., Setianingsih, E. S., \& Sulianto, J. (2019). Dampak Penggunaan Gadget terhadap Perkembangan Psikologi pada Anak Sekolah Dasar. Jurnal Ilmiah Sekolah Dasar, 3(4), 538. https://doi.org/10.23887/jisd.v3i4.22310

Tanuwidjaja, C. J., Ardianto, D. T., \& No, J. S. (2019). Perancangan Animasi Virtual Reality “ Slebor' Atau Ular Naga Sebagai Upaya Pelestarian Permainan Tradisional Di Indonesia. $1-9$.

Trilling, Berner. Fadel,Charles. 2009. $2^{\text {st }}$ Century Skills learning For Life in Our Times. San Fransisco: Jossey Bass.

Wardani, S. (2017). Media Pembelajaran Berbasis Animasi Untuk Pembelajaran Tematik Pada Siswa Sekolah Dasar. Dinamika Informatika, 6(1), 21-41.

Wena, Made. 2011. Strategi Pembelajaran Inovatif Kontemporer. Jakarta: Bumi Aksara.

Widjayanti, W. R., Masfingatin, T., \& Setyansah, R. K. (2019). Media Pembelajaran Interaktif Berbasis Animasi Pada Materi Statistika Untuk Siswa Kelas 7 Smp. 13(1), 101-112.

Wihartanti, L. V., Ramadhan Prasetya Wibawa, Rohana Intan Astuti, \& Pangestu, bayu aji. (2019). Penggunaan aplikasi quizizz berbasis smartphone dalam membangun kemampuan berpikir kritis mahasiswa. Prosiding Seminar Nasional Pendidikan Dan Pembelajaran 2019.

Wijaya, Ariyadi. 2012. Pendidikan Matematika Realistik. Yogjakarta:Graha ilmu. 
Winkanda. 2013. 99 Permainan Edukatif. Yogjakarta: Kata Hati.

Yamin, Martinis. 2010. Kiat Membelajarkan Siswa. Jakarta: Gaung Persada Press.

Yana, A. U., Antasari, L., \& Kurniawan, B. R. (2019). Analisis Pemahaman Konsep Gelombang Mekanik Melalui Aplikasi Online Quizizz. 7(2017), 143-152. https://doi.org/10.24815/jpsi.v7i2.14284

Yusuf, Y. (2019). Comparison Of Higher Order Thinking Skills (Hots) Ability Between Students That Using Multifunctional Smart Board Media And Powerpoint Media. 1(1), 15-22. 